Discourse and Communication for Sustainable Education, vol. 9, no. 1, pp. 100-114, 2018

\title{
Novice Teachers' Concerns, Early Professional Experiences and Development: Implications for Theory and Practice
}

\author{
Olena Zhukova \\ Daugavpils University, Latvia
}

\begin{abstract}
Quality teaching, being a key factor in shaping students' academic and personal growth, has been at the centre of scientific debate for many years. Sustainable professional development of novice teachers has recently been recognized worldwide as one of the key areas for improving the quality of teaching and learning in schools. Given that the initial years on the job are generally characterised by novice teachers as the most challenging and intense in their career, the following questions typically arise: What can be done to sustain and facilitate teaching at the early developmental stages in teachers' career? What are the contextual factors and the prerequisites leading to the quality of teaching and learning?

The article presents the findings from a two-year longitudinal qualitative study aimed to contribute to the research base for understanding this crucial stage. More specifically, the purpose of this study was to provide deeper understanding and insights into key factors influencing and shaping novice teachers' early professional development and learning, as well as their capacities to effectively adapt to their new roles and operate in complex and dynamically changing open-ended school environment. The research is framed as a cross-case analysis of 4 cases of novice teachers working in public secondary schools. The data were collected through multiple sources (i.e. semi-structured in-depth interviews, questionnaire, and focus groups) over a two-year period spanning the participants' first and second full-time teaching years. Substantial differences in experiences and beliefs among the novice teachers, with varying levels of job satisfaction and professional support received, were identified in the study. The authors have also identified numerous patterns of novice teachers' teaching practice closely associated with teachers'concerns and early professional experience interpretations, which might result in substantial fluctuation in teaching quality and teacher's career paths.

Implications for teacher education programs, mentoring, supervision, teachers' professional development, and future research are discussed.
\end{abstract}

Keywords: novice teacher, continuum of teacher development, induction, mentoring, education for sustainable development. 


\section{Introduction and Problem Statement}

The importance of research on novice teachers' professional development and early professional experiencesstems from the necessity to address the challenges faced by Latvian schools in the digital age, namely:

- Clear and urgent need to improve the quality of general education in order to prepare students to be productive, successful, socially and environmentally responsible,independent, and confident members of global society;

- The urgent need to reformand reorient the curriculum and the focus of general education in accordance with the principles of education for sustainable development;

- The entrance of young, talented, well-prepared, and commited newly qualified teachers into the teaching profession is often complicated or constrained, due to acombination of factors - namely, low salaries, decline in the social status of teaching, intense working conditions, and lack of newly qualified teachers' attraction, support and development system;

- Latvian teachers are the most senior in the European Union, and the teacher ageing in Latvia is more pronounced that in the European Union on average. Education in Latvia is the sector with the lowest share of young employees (Krasnopjorovs, 2017).

Quality teaching, being a key factor in shaping students' academic and personal growth, has been at the centre of scientific debate for many years. Sustainable professional development of novice teachers has recently been recognized worldwide as one of the key areas for improving the quality of teaching and learning in schools.

Given that the initial years on the job are generally characterised by novice teachers as the most challenging and intense in their career, the following questions typically arise: What can be done to empower and sustain teaching at the early developmental stages in teachers' career and what are the internal and external factors influencing novice teachers' professional and personal development and growth?

In the light of the competence-based education reformin Latvia, novice teachers will be confronted with additional requirements and challenges. Obviously, school education reformcannot beexpected to be effective if the teachers themselves are not prepared for them; teachers' abilities to develop systems thinking, sustainability thinking and attitudes towards education may play a decisive role in the success of theseeducation reforminitiatives.

Therefore, the aim of this longitudinal study was to investigate and expectantly provide deeper understanding of the development of novice teachers as they enter the teaching profession and develop their pedagogical expertise. The study also had as its aim to examine the factors affecting and shaping novice teachers' development over a two-year time period as they evolve from graduate students to professional educators, particularly focusing on the following major research question: How can we prepare teachers capable of establishing sustainable education practices and processes in schools? The following additional questions were also raised:

1) What is the nature of novice teachers' early professional development?

2) What are the factors that promote and/or hinder the novice teachers' capacities to adapt and effectively operate in complex dynamically changing open-ended 
school environment, as well as to learn how to deal with a complexity and uncertainty of a new environment?

3) How do novice teachers' concerns, pedagogical beliefs, and attitudes change and evolve over time? What kind of developmental stages do novice teachers go through and what are their concerns and support needs at each of these stages?

\section{Literature Review:}

\section{Novice Teachers’ Early Professional Development and System Thinking}

Teachers play vital role in shaping changes in students' values and attitudes, mindset, ways of thinking and seeing things, skills, behaviours and lifestyles consistent with sustainable development. Teachers' ability to think and act from a systems point of view and to incorporate systems thinking into their teaching practices, teachers' ability to approach teaching and learning process holistically, from a broader perspective, rather than in parts, as well as teacher's ability to understand causality is the foundation for reshaping and reorienting education to address sustainability. These fundamental skills and beliefs are developed gradually over time, influenced by teacher's increasing knowledge, personal and professional experience, personal maturity and inner growth. These skills and beliefs are also closely associated with teacher's adaptability capacities, and abilities to effectively cope with challenges and quickly adapt to complex dynamically changing open environments in school and beyond it (Iliško, 2010; Pipere, Veisson, \& Salìte, 2015; Iliško, 2015; Salìte et al., 2015; Iliško, 2016).

\section{Teacher Development Theories}

When addressing the concept of "teacher develpment", it is assumed that teacher's pedagogical beliefs, knowledge, teaching skills, attitudes, adaptability skills and abilities can be and actually are acquired and shaped gradually over time, in a certain sequence and under the influence of specific contexts (Katz, 1972; Conway \& Clark, 2003; Kagan, 1992; Vonk, 1989, Iliško, 2016, Salìte et al., 2015; Salīte, 2008). Typically, teachers' competence increases and improves with experience, and the knowledge and practice that come with it, which is consistently envidenced in literature (Katz, 1972; Ingersoll et al., 2014; Melnick \& Meister, 2008; Okas et al., 2014; Gerritsen et al., 2016; Jensen et al., 2012). Accordingly, it seems worthwhile and important to pay greater attention to teachers' developmental stages and the individual training and support needs that emerge and change based on these stages.

The initial years in teaching, encompassing the transition from "student" to "professional educator", are highly likely to have a considerable (and sometimes crucial) impact on teacher's future professional development, and it might be critical time for novice teachers to determine their professional beliefs, attitudes, practices, and philosophy for the rest of their career (c.f. Hudson, 2017; Okas et al., 2014; Helms-Lorenz et al., 2015; Owen et al., 2009; Andrews et al., 2012, Salīe, 2015). This stage in treachers' career involves teachers' attempts to transform their predominantly theoretical knowledge and beliefs into meaningful and effective practice in various real teaching contexts; furthermore, this stage leads tosignificant changes in teachers' ways of thinking, 
reasoning, and interpreting their experiences. The professional development of teachers therefore is considered to be the result of learning processes, directed towards the acquisition of an interrelated whole of knowledge, insights, attitudes, and skills which a teacher needs for the day-to-day adequate practice of his or her profession in a given school environment (Vonk, 1989). Furthermore, it is assumed that, the interactions between novice teachers and the environment result in a substantial change in the teacher's opinions, knowledge, attitudes, and skills (Vonk, 1989; Sadler, \& Klosterman, 2009; Franey, 2016; Levin, 2002). These processes can be characterised as explicitly uneven and non-linear, often proceeding not step by step but "in leaps" (Adams, 1982; Vonk, 1989; Franey, 2016). During the initial years of teaching teachers experience an incredible amount of growth and development influenced by their experiences in the classroom, their professional learning, and other internal and external factors. Research consistently shows that novice teachers are highly likely to have challenges in core professional practices including classroom discipline, motivating students, dealing with individual differences, assessing students' work, contacts with parents, the organization of class work, insufficient teaching materials and supplies, and problems of individual students (Veenman, 1984; Vonk, 1989; Jensen, et al., 2012; Okas, et al., 2014; Owen, et al., 2009; Andrews, et al., 2012).

According to a number of teacher development theories, based on the stages of concern in a teacher's career (c.f. Fuller, 1969; Burden, 1982; Burke, et al., 1984; Dubble, 1998; Katz, 1972; Watts, 1980; Vonk, 1989), a novice teacher goes gradually through three developmental phases, and at each of these phase the teacher's focus of concern is shifted from being predominantly self-concerned (e.g., survival, self-adequacy, and acceptance) to being task-concerned (e.g., student performance and teacher duties), and finally impact-concerned (e.g., social and educational impact on the system). It is assumed therefore that the novice teacher will not proceed to the next stage of concern without solving the concerns of the previous stage. The concerns-based teachers' development theories are still considered highly relevant, especially in the light of increasing number of research activities focusing onteacher professional preparation, development, beginning teacher quality, novice teacher retention and attrition (c.f. Franey, 2016; Conway, \& Clark, 2003; Levin, 2002; Levin, et al., 2013).

\section{Method}

The data for this longitudinal case study, involving four newly qualified teachers, were collected over a span of two years (2016-2017) as participants transitioned from their first to their second year of full-time teaching. The participants were employed as different subject teachers in basic, middle and high schools. The data were collected from multiple sources including a series of individual in-depth semi-structured interviews, focus groups, and questionnaires. Each interview was audio-taped, transcribed and further analyzed. The in-depths interviews were conducted in the end of each semester throughout the first and second teaching year in order to encourage novice teachers to reflect on and analyze the challenges and successes they experienced throughout their professional activity. Most interviews lasted about two hours and all were conducted at schools. The second data source was field notes taken during focus group discussions organized once a year (two focus groups discussions altogether) with all the participants 
to share experiences, concerns, and conceptions about multiple aspects of teacher's job, focusing on such aspects as teacher-student interactions, teacher's role, classroom management, general climate in the classroom, classroom activities and instruction. In addition, the focus groups explored such emerging themes as early-career learning, career plans, professional identity development and the types of support that participants had received from colleagues and school leaders. The focus group discussions were facilitated by one of the researchers and lasted for about two hours. Additionally, the participants completed Teachers Concerns Checklist, which served as third data source. The Teachers Concerns Checklist, consisting of 45 statements (Borich, 2000), based on Fuller and Bown's (1975) three-stage model of teacher development, was completed twice - at the end of the first and the fourth semester. Data from the in-depth interviews served as the primary data for the analyses conducted within the study, while the data collected through other sources were used as secondary data sources used to validate and complement the themes initially emerging from the analysis of the interview transcripts. The most prevailing themes were further summarized for each participant.

Initially data were collected from six participants. However complete two-year data sets from all three sources (interviews, focus groups discussions, and Teachers Concerns Checklist) were available only for four participants, therefore, based on the data availability, case studies were prepared for these four participants. The teachers surveyed were from various grade levels, including one primary school teacher. The participants and schools were chosen based on convenience and availability principle.

The participants of the study were coded as Anna (Case 1), Maria (Case 2), Alex (Case 3), and Sandra (Case 4), and their characteristics are presented below in Table 1. All names used are pseudonyms.

Table 1

Characteristics of the Participants

\begin{tabular}{|c|c|c|c|c|}
\hline & Gender & Age & Subject taught & Grades \\
\hline Anna (Case 1) & Female & 23 years old & $\begin{array}{l}\text { Teacher of English as a foreign } \\
\text { language. At the time of the research } \\
\text { she was a student of Master's program } \\
\text { in English Philology. }\end{array}$ & $7^{\text {th }}-12^{\text {th }}$ \\
\hline Maria (Case 2) & Female & 22 years old & $\begin{array}{l}\text { Primary school teacher, Organizer of } \\
\text { an extra-curricular drama club for } \\
\text { children }\end{array}$ & $1^{\text {st }}-4^{\text {th }}$ \\
\hline Alex (Case 3) & Male & 24 years old & Biology and Chemistry teacher & $6^{\text {th }}-9^{\text {th }}$ \\
\hline Sandra (Case 4) & Female & 24 years old & $\begin{array}{l}\text { Mathematics teacher. Holds Master } \\
\text { Degree in Education Management }\end{array}$ & $5^{\text {th }}-10^{\text {th }}$ \\
\hline
\end{tabular}

\section{Findings and Discussion}

The following specific themes explicitly emerged from the interviews and additional data sources: 1) novice teachers' concerns and challenges, 2) developmental shift of concerns 3) novice teachers' pedagogical beliefs and changes in teachers' pedagogical beliefs and philosophy, 4) inconsistency between teaching beliefs and classroom practices, and 5)novice teachers' professional training and support needs. 


\section{Novice Teachers' Concerns and Challenges, and Concerns Shift}

During four in-depth interviews and focus groups discussions, organized twice throughout this study, the respondents were asked to identify the professional areas that they find most challenging and troublesome, as well as the areas of their work they found most in need of further development. Furthermore, the participants were encouraged to offer their advice for overcoming these difficulties, as well as to reflect on their major concerns.

The findings clearly indicate that all four novice teachers in this study experienced a range of challenges and difficulties during their initial years in teaching, typically related to classroom management and discipline, organization of class work, time management, motivating students, dealing with students' individual differences and problems of individual students, managing resources, selecting and adapting curriculum and instructional materials and supplies. In the beginning and by the end of year one, all the participants reported being chiefly preoccupied with two clearly distinguishable groups of concerns: (1) their efforts to earn and maintain positive attitude and respect towards themselves, and (2) concerns about their performance in the classroom, concerns about time management, classroom management and discipline issues.

The teachers generally indicated that during their first year in teaching, and especially, during the first semester, they were largely preoccupied with the efforts to be accepted and appreciated by their students, students' parents, colleagues and school administrators, as well as "to perform well”, "to show good results", "to build good relationships with students and colleagues", "to earn respect and appreciation".

My classroom management skills are terrible. I love children very much; therefore, I always avoid yelling at them or raising my voice trying to calm them down or making them attentive and disciplined. I acknowledge that sometimes a teacher has to be authoritative and strict, but I am absolutely not this type of person. I want to be a friend, not an overseer. (Anna, Year 1 Interview)

Their concerns were predominantly focused on their classrooms daily routines, as well as centered around their own abilities to manage workload, to manage time-related constraints, to prepare "proper" lesson plans, to manage discipline issues, to cope with "difficult" and disruptive students, and to cope with their own stress and anxiety. Another group of concerns relates to teachers' efforts to control and regulate their own mental and emotional resources and well-being. The teacher repeatedly reported about being stressed, tired, frustrated, vulnerable, and professionally isolated. In addition, the teacher often felt professionally inadequate and weak in their teacher's role, especially during the first teaching year, because the job has proved to be unexpectedly intense, demanding, challenging, and with a lot of unforeseen situations, different from what they had learnt in their university classrooms and what they had practiced in a controlled environment during her practicum placements.

When I started teaching in school, I had to teach in 5 different level classes. Oftentimes I spent whole nights looking for interesting lesson ideas and attention-grabbing activities that would suit each of my classes and even each student. I tried my best to make a perfect lesson plan but when afterwards I 
walked into my classroom and started lesson, I realized that a lot of the activities I had planned did't work. I had to devote almost half of the lesson time to calming my kids down and struggling with the discipline. After such lessons I felt extremely disappointed and ineffective, despite the fact that I had demonstrated outstanding results while being a student teacher. Sometimes I even cried". (Sandra, Year 1 Interview)

The analysis of the second year data has revealed a range of substantial changes in the novice teachers' pedagogical beliefs, philosophy, and practices. With time and experience, the focus of teachers' concerns gradually shifted from parts to the whole, from short-term thinking to long-term thinking, from linear to systems thinking, from internal concerns of "self" to external concerns for student learning and for long-term impact.

\section{Developmental Shift of Concerns}

First year interviews and focus group discussion demonstrated that newly qualified teachers were highly likely to look for simple linear patterns to explain the processes in their classrooms and schools (e.g. teachers' explanations of students' behaviour, motivation, and poor learning outcomes were largely associated with more obvious and perceptible causes, such as "students' laziness", "negative influence of technology" and students' under-preparedness). In the course of gaining professional experience, teachers gradually began to realize that the processes occurring in their classrooms and in their school and also beyond it have deeper causes and roots, often indirect and poorly observable.

The ways of seeing things and understanding causality tend to shift from linear to system-like. Novice teachers demonstrated that their concerns shifted from being predominantly self-oriented and processes-oriented towards being oriented to casualty, dynamics, regularities and trends. Teachers' focus of concern shifted notably towards such aspects as diagnosing and understanding student learning problems, understanding individual student potential and helping reach it, recognizing the social and emotional needs of students and addressing them, understanding causes and mechanisms of students motivation, understanding the causes and mechanisms of students' progress and individual learning abilities, understanding the cause and effect of other variables (e.g. family and other social groups, physical and emotional health, nutrition, etc.) that affect students' learning, outcomes, behaviour, and motivation, seeking alternative and flexible ways to ensure students' progress, understanding students' psychological and cultural differences that affect learning and behaviour, guiding students toward intellectual and emotional growth.

I wanted to deeper understand my students' individual needs and abilities, as well as the mechanisms that guide their learning and motivation. To be honest, I have never thought about it before, during my teacher education and also during my first teaching year. I was sort of sure that some students are simply lazy and some are weak and some are not motivated and I was never curious and willing to understand why they were exactly like that and what I could do to change it. Now I realize that all kids are curious, motivated, creative, 
and each of them has his or her unique potential. We teachers have to be able to help each student reveal their unique areas of strength and hidden skills. (Alex, Year 2 Interview)

During the second teaching year and especially by the end of the second year the teachers generally tend to perceive themselves as capable of overcoming the difficulties and challenges of the first teaching year and cope with immediate day-to-day crises. The analysis of the Year Two interviews and Teacher Concerns Checklist indicate that the teachers tend to think more about the causalities and connections, trying to see the bigger picture and to understand the deeper and often unobservable underlying reasons of students' misbehavior, lack of interest and motivation, and low academic achievements. By the end of the second year the novice teachers started asking themselves such questions as "How can I help a particular misbehaving student to learn?Are there some other more effective ways of addressing discipline issues in the classroom, than those that I used before? What are the deep reasons for a particular student's misbehavior or learning difficulties and how can I influence it? Do all my students reach their full potential and how can I help them do it? What are the emotional needs of my students, how do they feel and how does it affect their motivation and learning progress? What are some innovative and more effective materials, techniques, ideas, and approaches to helping students' development?" Such questions emerged clearly in contrast to the first-year "surviving" questions about teachers' general abilities to manage stress and overload, to control the discipline in the classroom, to properly plan lesson, to manage the classroom, and to follow the curriculum. More importantly, some novice teachers' ways to see and evaluate education processes changed dramatically over time.

\section{Novice Teachers' Pedagogical Beliefs and Changes in Novice Teachers' Pedagogical Beliefs and Philosophy}

By the end of the second year, some teachers demonstrated noticeable changes in their beliefs as regards to teachers' and student's role, student motivation, and student discipline. In the middle and in the end of the second year teachers more often than in the first-year interviews mentioned the importance of student-centered instruction to enable lifelong learning and independent problem-solving. They emphasized the advantages of collaborative, active, and interdisciplinary learning, but at the same time expressed doubts about the ways such learning can be incorporated into today's school realia. By the end of the second year, all the participants emphasized the importance of studentcantered pedagogies and active learning, as well as the need to develop upper-level thinking skills, such as information synthesis, analysis, and evaluation, critical thinking and ability to think in systems (sustainability thinking), however at the same time three of the four teachersadmitted that they did not know how to achieve this due to the specific contexts in which they had to teach (pressure of the curriculum, large size classes, discipline issues). By the end of the second year all three teachers realized they wanted to rethink and reorient their teaching practices and approaches in order to remove the gap between what they thought was necessary and what they actually did in the classroom. 


\section{Inconsistency Between Teaching Beliefs and Classroom Practices}

The findings showed that the novice teachers' epistemological and other teaching beliefs (i.e. about teaching and learning, about children development, about curriculum, and classroom practices and instruction) were not always consistent with the way they taught. The findings have confirmed that in the beginning of their teaching career novice teachers hold a variety of beliefs about themselves, their subject matter, pedagogy, their students, about teaching and learning, as well as other personal beliefs (including moral values, attitudes, philosophy, and religious beliefs) that affect, shape and guide their behaviour in the classroom. Their beliefs are influenced by a range of internal and external factors and tend to change over time and with experience. However, the findings also indicate that the beliefs the teachers hold are not always present in their classroom practices due to a number of reasons, including contextual factors, as well as teachers' competence and mastery. The teachers repeatedly indicated in the interviews that they were consistently engaged in the classroom practices that they did not fully support, and only one teacher reported that she managed to enact her beliefs in her classroom practice.

They attributed this lack of congruence between beliefs and practices to various specific contextual factors (school culture, collegial influence, traditions in the school, class size, teaching resources available) as well as to the teachers' self-perceived level of professional adequacy and expertise.

I always plan a lot of student-centered and ICT-based activities, I prepare dozens of materials, but in the end I never manage to put it in practice. I cannot engage students, I cannot control time and discipline in the classroom, and therefore I often end up lecturing and other teacher-centered and course book-based activities, because it is simplier this way. (Anna, Year 1 Interview)

The teachers also explained that they had to adjust to the school requirements and "follow the traditional patterns" and balance the way they belief what teaching and learning should be and the way they "have to behave" in the classroom. The findings are consistent with those of previous studies by Pajares (1992), Levin (2002), Levin el al., (2013), Buehl, and Fives (2009).

\section{Novice Teachers' Professional Training and Support Needs}

The finding related the gap between novice teachers' expectations and needs regarding professional support and assistance, on one hand, and the support measures provided to them on the other hand.

The analysis of the first year data revealed that the novice teachers have a number of specific training and support needs during their first teaching year. Generally, the novice teachers require guidance, professional advice, understanding, appreciation, encouragement, support, and comforting. Furthermore, novice teachers lack direct assistance and professional advice regarding specific teaching skills and understanding the complex reasons and causes of their challenges, failures, crises, and conflicts in the classroom.

The first year was way too stressful. Unfortunately, when I started working in this school I had actually nobody to talk to or ask for help. The school is quite large, the administration is normally never available, and my colleagues 
were always busy and sometimes seemed not noticing me at all. There was a colleague who refused to share her teaching materials when I asked for them, which was quite discouraging and humiliating. It was only after half a year or so that I started feeling part of the team. (Sandra, Year 1, Interview)

All the participants pointed to the discrepancies between their expectations, anticipated success, and classroom realities, which inevitably caused feelings of unpreparedness and professional inadequacy. The findings also revealed that novice teachers are highly likely to associate distressful situations in their classrooms with their professional inadequacy. In order to resolve self-perceived professional inadequacy, the teachers typicallytend to reshape or lower their professional ideals and expectations.

\section{I think I would definitely require more training and advice as to how to deal with such students and such situations. When I was a student teacher we never discussed anything concerning indiscipline and disruptive student behaviour and so on. (Maria, Year 1 Interview)}

Strong concerns for professional development emerged only by the end of the third and fourth semester. During the second teaching year the teachers' professional development and support needs slightly changed, compared to the first teaching year. Schoolbased training and support was still very valuable; but additionally, teachers required deeper insight into the students' individual characteristics, learning styles and capacities, ways of understanding and addressing individual students' needs, learning, and behaviour difficulties. Exploration and analysis of individual problem cases with mentor and/or other colleagues seems to be very valuable form of professional development at this stage. Mentorship and supervision can be of great importance if it is aimed at not only helping novice teachers survive the first year, but also to empower them to impact student learning. Additionally, at this stage, school psychologists, social workers, child care and health specialists, and other related professionals might provide valuable information and assistance to sustain and strengthen the noviceteachers' knowledge and skills. Given that the participants of this study consistently reported about frequent disturbing feelings of their professional inadequacy and ineffectiveness, the teachers should be also given opportunity to share their concerns and emotions with other colleagues and/or mentor in order to lower their frustration, tension and feeling of professional inadequacy. Furthermore, by the end of the second full-time teaching year the teachers seem to be particularly interested in and open to participation in intense professional development activities, including experience exchange, classroom observation, collegial cooperation, team teaching, regional, and national conferences, meetings and workshops. They tend to demonstrate deeper interestin various teaching and learning theories, innovative approaches, methods, techniques and tools.

The participants were asked to reflect on the factors which they believed had been helpful in developing adaptability capabilities, as well as contributed to their professional mastery development. The teachers generally highlighted the importance of collegial support, systematic and targeted teacher professional development system and on-thejob training to help newly qualified teachers understand and learn to deal with the complexities of real schools and classrooms. 
ienced and effective teachers' feedback and analysis of my work in classrooms, which they sometimes had chance to observe. That was extremely useful for me. Sadly, we didn't have much time to meet and discuss everything I needed due to massive workloads and mismatch of our schedules. (Maria, Year 2 Interview)

The issues associated with teachers' emotional well-being should be more rigorously addressed during the teacher education and professional development courses, because teacher's emotional well-being and ability to cope with regular stress is likely to eventually have strong impact on students' learning. (Sandra, Year 2, Interview)

In the final interview round all the participants suggested that mentorship might have eased their transition into the profession and significantly enhance and sustain their teaching. The teachers agreed that collegial advice, decision making, discussions, and support is absolutely necessary to enhance and sustain their teaching, since such collaborative work allows to analyse and evaluate their pedagogical ideas, strategies they used, and to gain deeper understanding regarding their effectiveness. The teachers also acknowledged that their own strong professional commitment, ambition for selfdevelopment, and reflective teaching practices are highly likely to intensify the positive effects of mentorship and formal professional development.

In order to empower and sustain teaching, it is highly desirable to provide novice teachers with professional support, opportunities to discuss their concerns, and ask for practical advice on a range of topics concerning specific classroom contexts, sharing and discussing examples from real classrooms practices. (Anna, Year 2, focus group discussion)

Collaborative and supportive school environment, as well as availability of structured and systematic professional development and support system for novice teacher is absolutely necessary in order to help novice teachers develop their professional mastery in the most efficient way. (Alex, Year 2 focus group discussion)

\section{Conclusion}

At the initial stage in teachers' career, often referred to as "survival stage", newly qualified teachers tend to concentrate primarily on their personal concerns (concerns about their image, performance, status, acceptance), as well as on classroom management issues, instruction, and content knowledge. This stage in teacher's career also implies integration of multiple teaching skills and knowledge into a consistent whole to be used in the classroom (Franey, 2016). With time and experience, the focus of concern gradually shifts from part to the whole, from short-term thinking to long-term thinking, from linear to systems thinking, from internal concerns of self to external concerns for student learning. Only after passing this initial stage, the teachers' concerns become more taskand later impact-oriented, teachers become highly likely to be open to professional development, innovative ideas, and ready for change.

One of the most influential methods for helping teachers to successfully develop along their career path is to provide systematic differentiated professional development 
and support in accordance with their individual developmental stage, training and support needs. The findingsstrongly support the importance ofmentorship particularly during the induction phase when novice teachers transit form being a student teacher to professional educator. Positive effects of mentorship and novice teacher induction programs on teachers' progress and teaching quality are well documented in multiple scientific works (Feiman-Nemser, 2001; Flores \& Day, 2006; Helms-Lorenz et al., 2015; Henderson \& Noble, 2015). Mentorship emerged as an important issue in all four cases analysed within this longitudinal study. Novice teacher begin their teaching careers in very distinct settings, with different degree preparedness, different levels of collaborative environment and different levels of support provided to them from their colleagues and schools. Furthermore, novice teachers naturally come with different academic and personal backgrounds, as well as different philosophy, beliefs, abilities, knowledge and perspectives, influencing their individual development and performance. Therefore, they have diverse professional development and support needs at every stage of their professional identity development. The quality of teacher education and consequently the quality of teaching equally depends on the the quality of all stages in teacher lifelong professional development continuum, namely teacher education, the probationary (also induction or trainsition) period, early teaching experience, and subsequent teaching career. Having acknowledged the indivisibility andinterdependence of these stages, we cannot ensure high quality of teacher education if we continue considering it in isolation from the teaching career as a whole. Still little is being done to approach teacher education and professional development as a coherent whole, taking fully into account qualitative and quantitativechanges and transformations in the teacher's professional way of thinking and behaviours throughout his or her career, as well as their concerns, attitudes, expectations, and job satisfaction.

Understanding at which developmental stage the novice teachers are in their career might help schools provide differentiated professional development based on teachers' developmental levels. The findings of this study strongly suggest that current system of newly qualified teacher attraction, recruitment, retention, and support existing in Latvian schools does not provide adequate opportunity for a systematic, continuous, timely, and effective instructional, personal and professional growth. In order to address the problems associated with quality teachers shortage, which still remains a serious concern in Latvian context, as well as in order to ensure the adequate supply of well-prepared, high quality teachers capable of providing quality, competence-based education for sustainable development, the following two systems - (1) meaningful, systematic, and evidence-based support system for novice teachers, and (2) teacher attraction, selection, and retention system - seem to be critical factors for schools to ensure high quality teaching and learning for sustainable development.

Obviously, more targeted and systematic feedback and assistance is required to support teachers' professional growth and development throughout their career. A vision of a radically different teacher education and professional development system is emerging now - one that is approached as a coherent continuum encompassing interconnected developmental stages (i.e., teacher education, the initial years of teaching, and on-going teacher professional development and career) that are equally important for teachers' quality and effectiveness; the system that is capable of preparing teachers who are innovative, student-oriented "system thinkers", able to successfully adapt to and effectively operate in highly complex and dynamically changing school environment. 
Understanding the content of novice teachers' concerns, beliefs and experiences is significant for teacher educators, mentors, school leaders, and education policy makers, because these constructs influence and guide teachers' subsequent actions in the classroom and affect teachers' quality. It is especially important when education reforms are being implemented because the success of any education reform is highly dependent on teachers, their attitudes, abilities and willingness to adopt new initiatives.

\section{References}

Adams, R. D. (1982). Teacher development: A look at changes in teacher perceptions and behavior across time. Journal of Teacher Education, 33(44), 40-43.

Andrews, S. P., Gilbert, L., \& Martin, E. P. (2012). The first years of teaching: Disparities in perceptions of support. Action in Teacher Education, 28(4), 4-13.

Huberman, M. (Ed.). (1989). Research on teachers' professional lives. International Journal of Educational Research, 13(4), 343-466.

Bartlett, G. (2001). Systemic thinking. The paper presented at the international conference on thinking "Breakthroughs 2001." Prodsol International 2001.

Borich, G. D. (2000). Effective teaching methods (4 ${ }^{\text {th }}$ Ed.). Upper Saddle River, NJ: Merrill/Prentice Hall.

Buehl, M. M., \& Fives, H. (2009). Exploring teachers' beliefs about teaching knowledge: Where does it come from? Does it change? The Journal of Experimental Education, 77, 367-407.

Christensen J., Burke, P., Fessler, R., \& Hagstrom, D. (1983). Stages of teachers' careers: Implications for professional development. ERIC Clearinghouse on Teacher Education. Washington, DC.

Confait, S. (2015). Beginning teachers' challenges in their pursuit of effective teaching practices. Cogent Education, 2 (1). Retrieved from https://www.tandfonline.com/ doi/full/10.1080/2331186X.2014.991179

Conway, P. F., \& Clark, C. M. (2003). The journey inward and outward: A re-examination of Fuller's concerns-based model of teacher development. Teaching and Teacher Education, 19(5), 465-482.

Day, C. (1999). Developing teachers: The challenges of lifelong learning. London, UK: Falmer Press.

Feiman-Nemser, S. (2001). From preparation to practice: Designing a continuum to strengthen and sustain teaching. Teachers College Record, 103(6), 1013-1055.

Flores, M. A., \& Day, C. (2006). Contexts which shape and reshape new teachers' identities: A multi-perspective study. Teaching and Teacher Education, 22, 219-232.

Fuller, F. F. (1969). Concerns of teachers: A developmental conceptualization. American Educational Research Journal, 6, 207-226.

Fives, H., \& Gill, M. G. (2014). International handbook of research on teachers' beliefs. New-York, USA: Routledge.

Franey, J. J. (2016). Understanding teacher development theories. Developing Difference Makers. Retrieved from https://www.developingdifferencemakers.com/educationblogs/april-12th-201611

Frederiksen, L. L., Lund, J. H., \& Beck, M. (2016) Different understandings of the relationship between teacher education and professional practice. Journal of the European Teacher Education Network, 11, 112-120. 
Gerritsen, S., Plug, E., \& Webbing, D. (2016) Teacher quality and student achievement: evidence from a sample of Dutch twins. Journal of Applied Econometrics, 32(3), Retrieved from http://onlinelibrary.wiley.com/doi/10.1002/jae.2539/full

Henderson, R., \& Noble, K. (2015). Professional learning, induction and critical reflection: building workforce capacity in education. UK: Palgrave Macmillan.

Helms-Lorenz, M., Grift, W., \& Maulana, R. (2015) Longitudinal effects of induction on teaching skills and attrition rates of beginning teachers. School Effectiveness and School Improvement: An International Journal of Research, Policy and Practice, 27(2),178-204.

Hobson, A. J., Ashby, P., Malderez, A., \& Tomlinson, P. (2009). Mentoring beginning teachers: What we know and what we don't. Teaching and Teacher Education, 25, 207-216.

Hudson, B. (2017) Overcoming fragmentation in teacher education policy and practice. UK: Cambridge University Press.

Huling-Austin, L. (1992). Research on learning to teach: Implications for teacher induction andmentoring programs. Journal of Teacher Education, 43, 173-180.

Iliško, Dz. (2015). Locating sustainability in the Baltic States: Insights from ecofeminism. In Peppard, C., \& Vicini, A. (Ed.), Just sustainability. Technology, ecology, and resource extraction. USA: Orbis Books.

Iliško, Dz. (2016). Inquiry-based educational course in higher education towards sustainable communities: A case study. In Filho, L. \& Pace, P. (Ed.), Teaching education for sustainable development at university level. (pp. 125-145). The Netherlands: Springer.

Iliško, Dz. (2010). Educational encounters and interreligious education: A Latvian case study for expanding the borders of hospitality. InEngebretson K., de Souza M., Durka G., Gearon L. (Eds.). International Handbooks of Religion and Education, (pp. 191-202), Springer, Dordrecht. doi: https://doi.org/10.1007/978-1-4020-92602_12.

Iliško, Dz. (2016). Inquiry-based educational course in higher education towards sustainable communities: A case study. In Leal Filho W., \& Pace P. (Eds.), Teaching education for sustainable development at university level. World Sustainability Series. Springer, Cham. doi: https://doi.org/10.1007/978-3-319-32928-4_9.

Ingersoll, R. (2002). The teacher shortage: A case of wrong diagnosis and wrong prescription. NASSP Bulletin, 86, 16-31.

Ingersoll, R., Merrill, L., \& May, H. (2014). What are the effects of teacher education and preparation on beginning teacher attrition? CPRE Research Report \#RR-82. Philadelphia: Consortium for Policy Research in Education.

Jensen, B., et al. (2012). The experience of new teachers: Results from TALIS 2008, OECD Publishing. Retrieved from http://dx.doi.org/10.1787/9789264120952-en

Kagan, D. M. (1992). Professional growth among preservice and beginning teachers. Review of Educational Research, 62, 129-169.

Katz, L. G. (1972). The developmental stages of preschool teachers. Elementary School Journal, 73(1), 50-54.

Krasnopjorovs, O. (2017). Why is education performance so different across Latvian schools? Working paper 3/2017, Latvia: Latvijas Banka.

Levin, B. B. (2002). Case studies of teacher development: An in-depth look at how thinking about pedagogy develops over time. UK: Routledge. 
Levin, B. B., He, Y., \& Allen, M. H. (2013). Teacher beliefs in action: A cross-sectional, longitudinal follow-up study of teachers' personal practical theories. The Teacher Educator, 48, (3). Retrievd from https://www.tandfonline.com/doi/abs/10.1080/ 08878730.2013 .796029

Melnick, S. A., \& Meister, D. G. (2008) A comparison of beginning and experienced teachers' concerns. Educational Research Quarterly, 31(3), 39-56.

Okas, A., Van der Schaaf, M., \& Krull, E. (2014) Novice and experienced teachers' views on professionalism. Trames: Estonian Academy Publishers.

Okas, A. (2016) Novice and experienced teachers' practical knowledge in planning, delivery and reflection phases of teaching. Tartu: University of Tartu Press.

Owen, K., Broadhurst, K., \& Keats, G. (2009). Sink or swim? Learning lessons from newly qualified and recently qualified teachers. A report for the NASUWT. Birmingham: Perpetuity Research and Consultancy International (PRCI) Ltd.

Pajares, M. F. (1992). Teachers' beliefs and educational research: Cleaning up a messy construct. Journal of Educational Research, 62, 307-332.

Pipere, A., Veisson, M., \& Salite, I. (2015). Developing research in teacher education for sustainability: UN DESD via the Journal of Teacher Education for Sustainability. Journal of Teacher Education for Sustainability, 17(2), 5-43. doi: 10.1515/jtes2015-0009.

Sadler, T. D., \& Klosterman, M. L. (2009). Transitioning from student teacher to teaching professional: Evolving perspectives of beginning science teachers. Gainesville: School of Teaching \& Learning: University of Florida.

Salite, I. (2008). Educational action research for sustainability: Constructing a visionfor the future in teacher education. Journal of Teacher Education for Sustainability, 10, 5-17.

Salìte, I., Drelinga, E., Iliško, Dz., Oḷehnoviča, E., \& Zariņa, S. (2015a). Sustainability from the transdisciplinary perspective: An action research strategy for continuing education program development. Journal of Teacher Education for Sustainability, 18(2),135-152. doi: 10.1515/jtes-2016-0020.

Salite, I. (2015b). Searching for sustainability in teacher education and educational research: experiences from the Baltic and Black Sea Circle Consortium for educational research. Discourse and Communication for Sustainable Education, 6(1), 21-29. doi: 10.1515/dcse-2015-0002.

Salīte, I., Iliško, Dz., \& Mičule, I. (2015c). ISE action research: Reorienting teachers' dispositions towards ESD, Latvia. Leading practice publication: Professional development of university educators on Education for Sustainable Development in European countries, 105-107, ISBN: 978-80-87076-22-4, UE4SD Czech Republic.

Vonk, J. H. C. (1989). Beginning teachers' professional development and its implications for teacher education and training. The Irish Journal of Education, 23(1), 5-21.

Correspondence concerning this paper should be addressed to Olena Zhukova, Daugavpils University, Latvia. Email: lerial2@inbox.lv 